\title{
RiTAS Application Oriented to Ausubel Learning Theory for Social Studies Content: Validity and Feasibility
}

\author{
Ade Citia Dewi Ferdiansyah \\ Elementary School Teacher Education, University of Education Ganesha, Singaraja, Indonesia \\ e-mail: adecitiadewiferdiansyah19@undiksha.ac.id
}

I Gusti Agung Ayu Wulandari

Elementary School Teacher Education, University of Education Ganesha, Singaraja, Indonesia e-mail: ayu.wulandari@undiksha.ac.id

\section{A R T I C L E I N F O \\ Article history: \\ 25 December 2020 \\ Received in revised form \\ 01 January 2021 \\ Accepted 25 January 2021 \\ Available online 03 February \\ 2021 \\ Kata Kunci: \\ Teori Pembelajaran Ausubel; \\ Penelitian sosial \\ Keywords: \\ Ausubel Learning Theory; \\ Social Studies}

\begin{abstract}
A B S T R A K
Pelaksanaan pembelajaran online cenderung membuat siswa bosan jika hanya menggunakan media pembelajaran berupa video yang diambil dari youtube dan tugas yang diberikan guru melalui Google Classroom dan grup Whatsapp. Keterbatasan kemampuan guru dalam menggunakan media pembelajaran digital menjadi penyebab monotonnya media pembelajaran selama pembelajaran online. Tujuan penelitian ini adalah mendeskripsikan desain dan validitas aplikasi media pembelajaran yang dikembangkan. Penelitian pengembangan ini menerapkan model ADDIE. Pengumpulan data dilakukan dengan metode angket dengan instrumen angket. Analisis data menggunakan metode analisis deskriptif kualitatif dan kuantitatif. Subjek penelitian pengembangan ini adalah media pembelajaran berupa aplikasi android. Selanjutnya isi pokok bahasan direview oleh validator ahli, ahli desain pembelajaran, ahli media. Terakhir dilakukan uji coba oleh siswa secara individu dan kelompok kecil. Hasil analisis data berdasarkan validasi media oleh ahli materi diperoleh skor $92,8 \%$ dengan kualifikasi sangat baik, ahli desain pembelajaran memperoleh skor $87,5 \%$ dengan kualifikasi baik, ahli media pembelajaran memperoleh skor $85 \%$ dengan kualifikasi baik. Hasil uji coba individu pada 3 siswa diperoleh skor $90,1 \%$ dengan kualifikasi
\end{abstract} sangat baik dan tes melalui uji kelompok kecil pada 9 siswa diperoleh skor 90,9\% dengan kualifikasi sangat baik. Berdasarkan hasil analisis data uji produk oleh para ahli dan hasil pengujian pada siswa, disimpulkan bahwa media pembelajaran penelitian ini valid dan layak untuk digunakan dalam pembelajaran oleh siswa kelas VI.

\section{A B S T R A C T}

The implementation of online learning tends to make students bored if they only use learning media in the form of videos taken from YouTube and assignments given by the teacher through Google Classroom and Whatsapp groups. The limited ability of teachers to use digital learning media is the cause of the monotony of learning media during online learning. The purpose of this study is to describe the design and validity of the learning media application being developed. This development research applies the ADDIE model. Data collection was carried out by using a questionnaire method with a questionnaire instrument. The data analysis used qualitative and quantitative descriptive analysis methods. The subject of this development research is learning media in the form of an android application. Furthermore, the subject matter is reviewed by expert validators, learning design experts, media experts. Finally, the students conducted trials individually and in small groups. The results of data analysis based on media validation by material experts obtained a score of $92.8 \%$ with very good qualifications, learning design experts got a score of $87.5 \%$ with good qualifications, learning media experts got a score of $85 \%$ with good qualifications. The results of individual trials on 3 students obtained a score of $90.1 \%$ with very good qualifications and tests through small group testing on 9 students obtained a score of $90.9 \%$ with very good qualifications. Based on the results of the analysis of product test data by experts and the results of testing on students, it is concluded that this research learning media is valid and suitable for use in learning by grade VI students.

\section{Introduction}

The success and progress of a country is supported by an appropriate education system which create excellent and competent human resources (Anugraheni, 2017; Ramdani, et al., 2019). Teachers are an important factor in education, especially as creators of the learning process. Teachers are required to be able to create effective learning (Wulandari \& Agustika, 2018). The teacher is a person who has the authority and responsibility in guiding and fostering students (Hamid, 2017). During the pandemic, according to Circular Letter Number 4 of 2020 concerning the Implementation of Education Policies in an Emergency for the Spread of COVID, it is informed that the learning process is carried out at home through online learning. Online 
learning is an effort to overcome educational problems regarding the implementation of learning during a pandemic (Malyana, 2020). Online learning is an effort to overcome educational problems regarding the implementation of learning during a pandemic. Online learning provides flexibility for students to learn anytime and anywhere through applications such as classrooms, video conversion, zoom or whatsapp groups (Dewi, 2020). However, in reality there are still many obstacles in online learning. Some of the obstacles such as decreased student interest in learning, limited supporting facilities such as internet and smartphone networks, unability parent to accompany their children since be at work, and the limited ability of teachers to develop digital learning media. This is as stated by Sulistyawati (2020) the difficulty of internet network connection, people who have difficulty operating, is the reason students have difficulty participating in online learning. The difficulties experienced by students cause students quickly bored and lazy to take part in learning. The learning process at home causes children feel anxiety, stress, sadness, boredom, and yawnful, thus decreasing their interest in learning (Wardani \& Ayriza, 2020). Limited knowledge of learning media that is in accordance with the material being taught is one of the obstacles for teachers in the learning process (Anugraheni, 2017). The use of technology in learning that has not been optimal has resulted in a decrease in student motivation and interest in learning (Syawaludin et al., 2019).

One of the efforts that can be made for this problem is to provide innovation in the use of learning media.Learning media is anything that is used to convey messages / learning materials that can stimulate, attention, interests, thoughts and feelings of students in learning activities in achieving learning objectives (Firdaus, 2018). Through learning media students can be directly involved and actively use the media in learning (Wahyuningtyas \& Sulasmono, 2020). The importance of learning media is used to increase the learning interest of elementary school students (Supriyono, 2018). The use of learning media that attracts students' attention is expected to have an effect on students to focus on paying attention to the content of the learning media. The use of instructional media also determines the success of the learning process (Astuti et al., 2017). The choice of media should be based on several considerations such as student needs, suitability with learning objectives, suitability of material, and suitability of learning methods (Hadi, 2017). Types of learning media can be in the form of visual media relying on the sense of sight, audio media using the sense of hearing, audio-visual media that rely on the senses of sight and hearing, and multimedia which is a medium that involves several types of media and integrated equipment in learning (Widyastuti, 2017).

The rapid development of information and communication technology is related to the world of education. The use of technology in the form of smartphones in creating learning media can increase student interest in learning (Dini Savitri et al., 2020). Learning media in the form of an android application can be an alternative for teachers to carry out more interesting learning (Sudrajat, 2018). The development of this application learning media is an effort to provide solutions to problems that occur during the online learning process. Learning media in the form of this application can be accessed on an android smartphone with or without an internet network. In the developed application, besides containing reading text, it also contains images, videos, and audio to support the attractiveness and effectiveness of the media being developed. In the application, there is also a question quiz that concerns the content of the material in the application and provides direct reinforcement which then the scores obtained can be received directly by the teacher via email. Application is a subclass of computer software that is used to perform a task from the user (Tambunan et al., 2017). The opinion expressed by Susilo (2017) learning media applications can be used as supporting media for learning in all materials. The attractiveness of application learning media affects users' interest and motivation in learning (Erfan et al., 2020). Android learnin g media provides opportunities for students to learn according to their learning abilities (Batubara, 2017). Applications as learning media that can be accessed on smartphones and tablets based on Android so that students can learn independently wherever and whenever (Kharisma \& Arvianto, 2019). Android-based learning media has advantages such as an attractive design appearance in terms of colors, writing, images, and animation besides that it is also easy to operate and understand by students (Muyaroah \& Fajartia, 2017). Research conducted by Syawaludin et al., (2019) found that learning media were attractive applications that helped increase students' enthusiasm and enthusiasm for learning. Learning media in the form of an Android-based application are easy to use and can be used anywhere and make it easier for students to learn (Prasetyo, 2017). In a study conducted by (Kartini \& Putra, 2020) found the results of research regarding student responses to application learning media were very good so that interesting learning made students happier and easier to absorb knowledge during the learning process. The use of application learning media also makes it easy for teachers to deal with problems in delivering material (Lubis et al., 2019). Based on this study, an Android-based application learning media was developed which contains text, images, audio, and video. This application was created with Microsoft Powerpoint and iSpring Suite 9. This application can only be accessed on an Android smartphone via the install link that is shared via Google Drive. Referring to research that is relevant to the development of learning media for the application of social studies content, especially ASEAN material, there is still few research regarding this subjects. Such as research conducted by Astridefi et al.,(2016) which only displays 3D videos of ASEAN material, the scope of research by Susilo, (2017) only discusses sub- 
main definitions, objectives, cooperation, symbols, and the application developed by Sudrajat, (2018) has a simple appearance and only chooses 2 sub-topics, namely history and state identity. Moreover, the available application on Google PlayStore still doubtful because the product is unvalidated. The application called RiTAS (Mari Tahu ASEAN) contains ASEAN material. The material in this application adapts to the needs and characteristics of students. Students can choose type of material tha wish to study. The scope of material in the application is based on KD and indicators in the 2013 Curriculum syllabus. The sub-topics of the application consist of 5 subjects, namely history, geographical characteristics, economic life, socio-cultural life, and political life of 10 ASEAN member countries. The application is also equipped with quizzes to motivate students' enthusiasm for learning by reinforcing questions related to the material in the application. Using the application is very easy because of the consistency of the buttons on the application.

The purpose of this research can be formulated to describe the design process of learning media for applications containing material on geographical characteristics and the socio-cultural, economic and political life of ASEAN countries and to describe the validity of applications according to experts, product testing includes individual trials and small group trials. Through the development of learning media Android applications can be used as a solution to the difficulties and obstacles by students and teachers. This application learning media can be accessed anytime and anywhere with or without an internet network. The use of this research is to be used in learning activities in schools to make it more attractive, interactive, effective, and efficient, especially on the ASEAN sub-topic.

\section{Method}

This type of research is development research $(\mathrm{R} \& \mathrm{D})$ where the application development process is carried out by applying the ADDIE model. According to (Tegeh \& Kirna, 2010) the ADDIE model has systematic steps and is based on the theoretical foundation of learning design. The ADDIE model includes the analysis, design, development, implementation and evaluation stages, the five stages are carried out systematically (Dini Savitri et al., 2020). The ADDIE model is arranged in a systematic sequence of stages in an effort to solve learning problems related to learning resources according to the needs and characteristics of students (Wisada et al., 2019). This research was conducted at SD Negeri 3 Celuk, Sukawati, Gianyar. The subject of this research was learning media in an application form which is an android-based application that can be accessed on a smartphone.

The data collection in this development research used a questionnaire method. The questionnaire method was used when analyzing student characteristics, product testing on trial subjects, namely subject content experts, learning design experts, instructional media experts, individual trials, and small group trials on students. The experts consist of 1 content expert who is a lecturer at the Ganesha University of Education who teaches the Social Studies Education course, 1 instructional design expert, and 1 instructional media expert, which is a lecturer at the Ganesha University of Education with educational technology qualifications. While the individual trial was conducted on 3 students in grade VI, and the small group trial involved 9 students in grade VI SD Negeri 3 Celuk, Sukawati, Gianyar.The questionnaire used a closed questionnaire consisted of 14 statement items in the subject content expert questionnaire consisting of 3 aspects, namely aspects of media material, and evaluation, 10 statements in the learning design expert questionnaire consisted of 3 aspects, namely curriculum, content, and strategy, 10 statement items on the instructional media experts consist of 5 aspects, namely appearance, text, images, color, and sound, and the 11 statement items in the student questionnaire consist of 6 aspects, namely appearance, text, pictures, motivation, material, and evaluation. All statements in the questionnaire are positive statements. The grid for the product assessment instrument for the RiTAS application is as follows. The data analysis used in this development research is descriptive quantitative and qualitative descriptive analysis method. In this study, quantitative descriptive analysis was used to process the data obtained through a questionnaire in the form of scores. The criteria is established to give meaning to the percentage score and decision making on the feasibility of the product being developed are as follows.

Table 1. The Instrument Grid of Subject Content Expert

\begin{tabular}{llcc}
\hline \multirow{2}{*}{ Aspect } & \multicolumn{1}{c}{ Component } & $\begin{array}{c}\text { Question } \\
\text { Number }\end{array}$ & $\begin{array}{c}\text { Quantity } \\
\text { of Item }\end{array}$ \\
\hline Subjects & a. Learning media can motivate students & 1 & 1 \\
& b. The learning media provided attracted attention. & 4 & 1 \\
& c. Helps memorize previous learning and cognition & 14 & 1 \\
& d. Material accuracy & 2,7 & 2 \\
& e. The material is useful for students in real life & 3 & 1 \\
& f. Consistency between objectives, materials and evaluation & 7,12 & 1
\end{tabular}




\begin{tabular}{llcr}
\multirow{5}{*}{ Media } & g. The material is easy to understand & 6 & 1 \\
& a. The language used is clear & 5 & 1 \\
\multirow{5}{*}{ Evaluation } & b. Instructions for use are provided & 9 & 1 \\
& c. Use pictures and photos that support learning & 11 & 1 \\
\hline & a. Provide an evaluation to measure students' abilities & 12 & 1 \\
& b. Provide feedback on evaluation results & Total & \\
\hline
\end{tabular}

(Source: Suartama, 2016)

Table 2. The Instrument Grid of Learning Design Expert

\begin{tabular}{|c|c|c|c|}
\hline Aspect & Component & $\begin{array}{l}\text { Question } \\
\text { Number }\end{array}$ & $\begin{array}{l}\text { Quantity of } \\
\text { Item }\end{array}$ \\
\hline \multirow{3}{*}{ Curriculum } & a. Suitability of learning indicators with basic competencies & 3 & 1 \\
\hline & b. The indicator conforms to the ABCD format & 1 & 1 \\
\hline & c. Conformity of learning objectives with indicators & 2 & 1 \\
\hline \multirow{5}{*}{ Content } & a. The suitability of the material content & 4 & 1 \\
\hline & b. Material with appropriate basic competencies & 5 & 1 \\
\hline & $\begin{array}{l}\text { c. The material helps students remember previous } \\
\text { knowledge }\end{array}$ & 7 & 1 \\
\hline & d. The material corresponds to cognitive development & 6 & 1 \\
\hline & e. Learning provides examples of everyday life & 8 & 1 \\
\hline \multirow{2}{*}{ Strategy } & a. Evaluation helps students improve competence & 9 & 1 \\
\hline & b. The instructions are clear & 10 & 1 \\
\hline \multicolumn{3}{|c|}{ Total } & 10 \\
\hline
\end{tabular}

(Source: Suartama, 2016)

Table 3. The Instrument Grid of Learning Media Expert

\begin{tabular}{|c|c|c|c|}
\hline Aspect & Component & $\begin{array}{l}\text { Question } \\
\text { Number }\end{array}$ & $\begin{array}{l}\text { Quantity } \\
\text { of Item }\end{array}$ \\
\hline \multirow[t]{3}{*}{ Display } & a. Ease of use & 1 & 1 \\
\hline & b. Display quality & 6 & 1 \\
\hline & c. Button consistency & 3 & 1 \\
\hline \multirow[t]{3}{*}{ Text } & a. Legibility & 7 & 1 \\
\hline & b. Writing color & 2 & 1 \\
\hline & a. Font size & 10 & 1 \\
\hline Picture & a. Image suitability & 8 & 1 \\
\hline Color & $\begin{array}{l}\text { a. The proper and harmonies composition and color } \\
\text { combination }\end{array}$ & 4 & 1 \\
\hline \multirow[t]{2}{*}{ Sound } & a. Use of appropriate music & 9,5 & 2 \\
\hline & Total & & 10 \\
\hline
\end{tabular}

(Source: Suartama, 2016)

Table 4. The Instrument Grid of individual and small group test

\begin{tabular}{|c|c|c|c|}
\hline Aspect & Component & $\begin{array}{l}\text { Question } \\
\text { Number }\end{array}$ & $\begin{array}{c}\text { Quantity of } \\
\text { Item }\end{array}$ \\
\hline \multirow{3}{*}{ Display } & 1. The attractiveness of learning media & 1 & 1 \\
\hline & 2. Ease of use of medi & 3 & 1 \\
\hline & 1. Text legibility & 4 & 1 \\
\hline \multirow[t]{2}{*}{ Text } & 2. Use of appropriate fonts & 2 & 1 \\
\hline & 3. Use the appropriate font siz & 5 & 1 \\
\hline Picture & 1. Use of images that match the material & 6 & 1 \\
\hline Motivation & 1.Media can generate student motivation & 7 & 1 \\
\hline Material & 1.The material is easy to understand & 9 & 1 \\
\hline
\end{tabular}




\begin{tabular}{clcc}
\hline Aspect & \multicolumn{1}{c}{ Component } & $\begin{array}{c}\text { Question } \\
\text { Number }\end{array}$ & $\begin{array}{c}\text { Quantity of } \\
\text { Item }\end{array}$ \\
\hline \multirow{3}{*}{ Evaluation } & 2. The learning objectives are easy to understand & 11 & 1 \\
& 1. Suitability questions & 8 & 1 \\
& 2. Provide feedback on the results of the evaluation. & 10 & 1 \\
\hline \multicolumn{1}{c}{ Total } & $\mathbf{1 1}$ \\
\hline
\end{tabular}

(Sumber: Suartama, 2016)

Table 6. Conversion of Achievement Level Scale 5

\begin{tabular}{cccc}
\hline No & Achievement Level (\%) & Qualification & Description \\
\hline 1. & $90-100$ & Very good & No need to revise \\
2. & $75-89$ & Good & Minimum revision \\
3. & $65-74$ & Enough & Moderate Revision \\
4. & $55-64$ & Less & Major Reveision \\
5. & $0-54$ & Very less & Reproduced new product \\
\hline
\end{tabular}

(Source: Tegeh \& Kirna, 2010)

\section{Result and Discussion}

The results of this study include the design and development of learning media application development and the validity of application learning media. The design and development of this application media development used the ADDIE development model.The design and development of this application media development used the ADDIE development model. Includes the analysis, design, development, implementation and evaluation stages (Tegeh, 2014). The development stages that have been carried out are as follows.

The first stage, namely the analysis stage, carried out the process of analyzing teacher needs and student characteristics in learning, analyzing the material to determine KD and indicators. Analysis of teacher needs in learning through interviews found that teachers only used learning videos taken from YouTube and gave assignments through Whatsapp groups or Google Classroom. Teachers have not been able to develop interesting and innovative digital learning media. Therefore, we need an interesting and innovative media. Especially media that contains meaning, because meaningful learning can help students easily understand the material and remember the material for a longer period of time (Muamanah, 2020). Analysis of student characteristics through questionnaires shows that students are comfortable to learn by using interesting media, contains videos and images, and is meaningful such as applications, in addition to video learning media only or assignments obtained from school. In the analysis of student characteristics, it was also found that some students already have personal smartphones and all students are able to operate smartphones. KD analysis and indicators were carried out through observation, it was known that the syllabus contained KD and indicators of ASEAN material with Basic Competencies 3.1 Identify geographical characteristics and social, cultural, economic, political life in the ASEAN region and indicators tell the history of ASEAN, analyze the geographical characteristics of ASEAN countries, compare the socio-cultural life of ASEAN countries, differentiate the economic life of ASEAN countries, and show political life ASEAN countries, Shown in the pigure 3.

The design stage is carried out by the process of designing a product which includes activities (a) Compiling the material that will be in the application in the form of a concept map. (b) Create a flowchart from the application learning media (c) Arrange a storyboard to describe the appearance of the application learning media. (d) Prepare a learning implementation plan (RPP) as a reference for implementing learning activities using an online application. (e) Developing a product assessment instrument for experts and students, namely in the form of a questionnaire to determine the validity of the developed application.

The third stage is the development stage, starting from producing the application until it is ready to be tested on experts and students. The stages of development using Microsoft Office Power Point start from the activities (a) creating an interface design or initial appearance when the application is used, (b) creating content in the application, (c) adding interactivity to the interface to enable the buttons in the application (d) creating quiz practice questions using iSpring Suite 9 in Microsoft Office Power Point, (e) creating application logos as product identities, (f) publishing powerpoints to HTML 5 using iSpring Suite 9, (g) building HTML 5 into android applications with web 2 apk builder pro v3.4, (h) downloading the application on an android smartphone.

After the application is finished production the next stage is the implementation stage. Implementation trials product on trial subjects, namely subject content experts, learning design experts, instructional media experts, and students through individual trials and small group trials. Product trials were carried out to determine the validity of the products that will be used in the learning process. The last stage is the evaluation stage, the 
evaluation is carried out is a formative evaluation that is carried out during the development process, the goal is to improve the product being developed. The results obtained from the test subjects are used as a benchmark for improving or perfecting the product being developed.

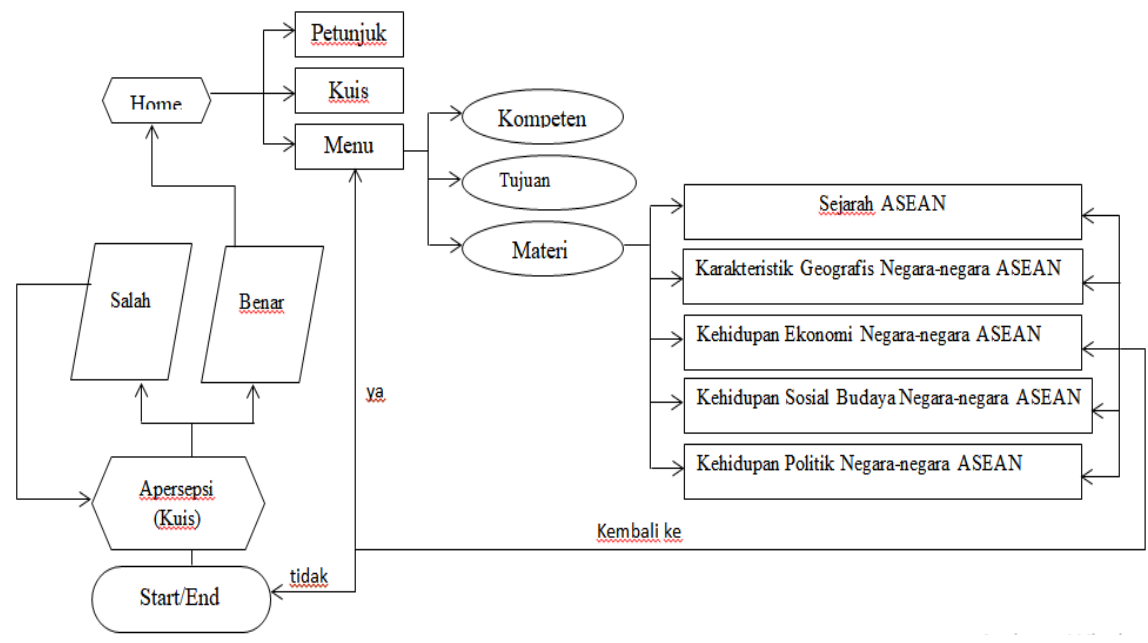

Figure 1. Flowchart of Application Learning Media Development

Product testing by trial subjects, namely subject content experts, learning design experts, instructional media experts and students through individual trials and small group trials. The product trial process was assessed using a questionnaire instrument. The trial activity aims to determine the validity of the product being developed. The learning content was assessed by content experts, namely lecturers who teach social studies education, design and learning media are assessed by experts, namely lecturers with educational technology qualifications. Individual trials with three students in grade VI who have high, medium and low learning outcomes at SD Negeri 3 Celuk, Sukawati, Gianyar, and small group trials conducted by 9 students in grade VI at SD Negeri 3 Celuk, Sukawati, Gianyar with Heterogeneous groups each of 3 students with high, medium and low learning outcomes. The following are the results of product trials by test subjects.

Table 7. Percentage of Application Product Trial Result Score

\begin{tabular}{lcc}
\hline \multicolumn{1}{c}{ Trials Subject } & Result $(\boldsymbol{\%})$ & Qualification \\
\hline Subject content expert & 92,8 & Very good \\
Learning design expert & 87,5 & Good \\
Learning media expert & 85,0 & Good \\
Individual Trial & 90,1 & Very good \\
Small Group Trial & 90,9 & Very good \\
\hline
\end{tabular}

Based on the results of product trials that have been carried out by subject content experts, the result is a percentage score of $92.8 \%$ with very good qualifications. The learning design expert obtained a percentage score of $87.5 \%$ with good qualifications. Learning media experts get a percentage score of $85 \%$ with good qualifications. The results of individual trials obtained a percentage score of $90.1 \%$ with very good qualifications. The results of the small group trial obtained a percentage score of $90.9 \%$ with very good qualifications. From the results of product trials, it can be concluded that the product of the RiTAS application developed is valid for use in the learning process. However, in the product testing process there were comments, responses and suggestions from experts that are to improve or enhance the product. Below is a summary of comments and suggestions provided by experts and test subjects.

Table 8. Comments and Revision

\begin{tabular}{ccll}
\hline No & \multicolumn{1}{c}{ Trials Subject } & \multicolumn{1}{c}{ Comments } & \multicolumn{1}{c}{ Revision } \\
\hline 1. & Subject content expert & Learning objectives are not & Improve learning objectives to \\
& & suitable. & meet the indicators. \\
& & $\begin{array}{l}\text { Multiplied the material for sub- } \\
\text { topic of political life }\end{array}$ & $\begin{array}{l}\text { Add the discussion of the political } \\
\text { life in ASEAN country }\end{array}$
\end{tabular}




\begin{tabular}{|c|c|c|c|}
\hline No & Trials Subject & Comments & Revision \\
\hline 2. & Learning design expert & $\begin{array}{l}\text { Recommended to use cognitive } \\
\text { realm indicator to analyze }(\mathrm{C} 4) \text {, } \\
\text { evaluate }(\mathrm{C} 5) \text {, and create }(\mathrm{C} 6) \text {. }\end{array}$ & $\begin{array}{l}\text { Adjusting the indicators using } \\
\text { KKO in the cognitive domains to } \\
\text { analyze (C4), evaluate (C5), and } \\
\text { create (C6). }\end{array}$ \\
\hline 3. & Learning media expert & $\begin{array}{l}\text { Improved the questions } \\
\text { Fix the color of the writing to } \\
\text { make it more interesting }\end{array}$ & $\begin{array}{l}\text { Create evaluation questions into } \\
\text { HOTS questions and background. } \\
\text { Improve the color of the writing to } \\
\text { be more colorful }\end{array}$ \\
\hline & & $\begin{array}{l}\text { Rearrange paragraphs of material } \\
\text { in the application }\end{array}$ & $\begin{array}{l}\text { Arranging material paragraph text } \\
\text { in the application }\end{array}$ \\
\hline
\end{tabular}

Table 9. Comments and Suggestions for Individual Test Subjects

\begin{tabular}{cl}
\hline No & \multicolumn{1}{c}{ Trial Subjects } \\
\hline 1. & Excellent, it attratcs me to learn \\
2. & The music is fine, it doesn't distract concentration \\
3. & The media is pleasant, suggest to create for other materials \\
\hline
\end{tabular}

Table 10. Comments and Suggestions for Small Group Test Subjects

\begin{tabular}{cl}
\hline No & \multicolumn{1}{c}{ Trial Subjects } \\
\hline 1. & The meda is excellent and interesting \\
2. & The application attracts enthusiastic for learning \\
3. & This application is exciting because contains quizzes \\
\hline
\end{tabular}

Based on the results of the research that has been done, application development obtains good and very good qualifications from the assessment of the test subjects, namely experts and students, so that the application developed is valid for use in the learning process.

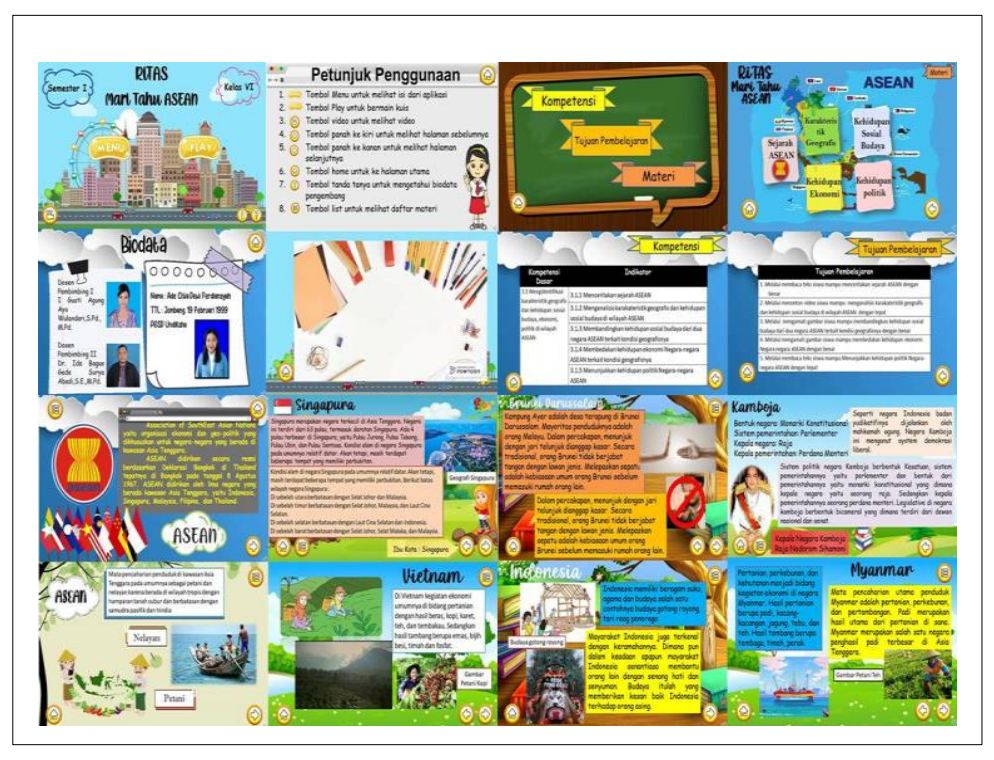

Figure 2. Results of the Development of Learning Media for RiTAS Applications

Based on the questionnaire for content experts, the results of the assessment of the media obtained a percentage of $92.8 \%$ with very good qualifications. This is because the material presented is in accordance with the basic competencies, indicators, and cognitive development of students. The material presented in the application attracts students' attention. The suitability of the material with evaluation or practice questions does not make students confused and feedback in the form of reinforcement when working on practice questions motivates students to be more enthusiastic about learning. Apart from being in the form of words, the material in the learning application is also supported by the presentation of images and videos. Pictures and videos are 
useful for clarifying a situation, so that pictures and videos will make it easier for students to remember and understand the material presented. used in developed applications, get a percentage of $87.5 \%$ with good qualifications. Nida \& Dkk, (2020) mentioned that learning media equipped with images and text made students easy to learn because of the interesting learning media.

The results of research on product trials by instructional design experts, which were plan, there are learning objectives that are in accordance with the indicators and are clearly arranged according to the ABCD format (audience, behavior, condition, degree). When viewed from the material aspect, the material in the learning application is in accordance with ASEAN material and basic competencies so that students understand the material correctly. The material is also adapted to the cognitive development of students, it helps students develop knowledge and critical thinking. If observed from the evaluation aspect, the instructions for working on evaluation questions in the learning application are easy to understand and the evaluation questions are in accordance with the learning objectives. Knowing the characteristics of students in advance is an important part of designing learning so that a fun learning process occurs. The learning strategy to be used must be clear in carrying out learning so that learning objectives can be achieved. Agree with Hermawan's opinion (2009) RPP contains activities, assessments, methods, and media to achieve learning objectives.

The results of product trials by instructional media experts get $85 \%$ results with good qualifications. because when viewed from the appearance of the application, the background used in the learning application is attractive, the display is in accordance with the characteristics of the student, the display design can attract students' interest, the color combination used is good so it looks attractive, the button layout position is set appropriately, the button size has been set correctly, each button can be operated smoothly, the text can be read well, the font type is set correctly, the font size is correct, the text color is in contrast to the background color, the image quality is good, the image is in accordance with the material, the video can be clearly visible, and the backsound used is appropriate, and the language used also makes it easier for students to understand the use of the application. This is supported by the opinion of Sriwitari \& Widnyana, (2014) explained that the strength of color is very influential from the background, using contrasting colors will make the text more alive. The application is very easy to download, easy to operate, not difficult to run, and does not stop when running. This is because the size of the application is not too large and can be used without having an internet connection. Display design, color combinations, button layout, font types, images, video, and audio are very important to be adjusted to the characteristics of students in order to attract students' interest in learning applications. Pictures and videos are devoted to clarifying a situation because they can show students a real situation, so that pictures and videos will make it easier for students to remember and understand the material presented. Supported by the opinion of Sudarma, (2015) explaine that images can help students understand the meaning of the text. The images and videos that are included must be relevant to the material presented because they will affect the clarity of the message in the material displayed in the learning media. The material presented with pictures makes it easy for students to understand a concept so that there are no wrong perceptions and the material becomes easy to memorize.

The results of user trials through individual trials and small group trials from student assessments of the application product developed obtained a percentage result of $90.1 \%$ in individual trials and $90.9 \%$ in small group trials with very good qualifications. If reviewed again, validation in individual trials gets a percentage of $90.1 \%$ with very good qualifications and validation in small group trials gets a percentage of $90.9 \%$ with very good qualifications. Learning applications get very good qualifications because the design of attractive learning applications such as the theme of the learning application, the color combinations used, the layout of the buttons, the type of writing fonts, the presentation of images, animation, video presentation, and audio presentation are arranged and arranged appropriately so that it becomes an application. learning that has an attractive design so that it can make students interested in using learning applications.Agree with (Nurseto, 2012) saying that music arouses student interest, reduces boredom, and affects the listener's psyche. The existence of an explanation of the material in the form of text coupled with the presentation of images and animations in the material display is what makes students more enthusiastic about learning because it really helps students to interpret the messages conveyed in the material text. Pictures and animations provide a depiction of what happens that cannot be explained only through text messages so that images and animations are used to support the effectiveness of learning applications.Agree with (Mirnawati, 2020) saying that students prefer to read text that contains images because reading becomes more interesting. This is because the size of the application is not too large and can be used without having an internet connection. When viewed from the evaluation aspect, the sentence evaluation questions used in the learning application are easy to understand by students.

Based on these data it can be concluded that the learning media for the RiTAS application contains IPS sub-material on geographical characteristics and the socio-cultural, economic and political life of ASEAN countries in class VI at SD Negeri 3 Celuk, Sukawati Gianyar was declared valid because it has very good qualifications based on the results of testing by test subjects and has received positive comments in the development of media applications. This is supported by Tahel's research (Tahel \& Ginting, 2019) which states 
that application learning media can be used to help students understand the material and attract students' interest in learning the material. In addition, Ayun's research (Ayun \& Rahmawati, 2018) shows that application learning media is an interactive learning medium so that students can participate and be active during the process. learning. The RiTAS application is packaged as an interesting and meaningful medium, the application presents perceptions by linking previous knowledge in accordance with Ausubel's learning theory. The RiTAS application as a learning medium can increase student motivation and interest in learning and help students understand material for a long time and learn independently according to learning objectives. The implication of using the application as a technology-based learning media is interesting because of the right color combination and the exposure of the material that is included with images, videos, and animations as support. This learning media application can be a collection of digital learning media in elementary schools. Assisting teachers in improving their abilities in developing technology learning media.

\section{Conclusion}

Based on these data it can be concluded that the learning media for the RiTAS application contains social sub-material on geographic characteristics and the socio-cultural, economic and political life of ASEAN countries in class VI at SD Negeri 3 Celuk, Sukawati Gianyar was declared valid and can be used as a learning medium.

\section{References}

Anugraheni, I. (2017). Analisa Faktor-Faktor yang Mempengaruhi Proses Belajar Guru-Guru Sekolah Dasar. Kelola: Jurnal Manajemen Pendidikan, 4(2), 205. https://doi.org/10.24246/j.jk.2017.v4.i2.p205-212.

Astridefi, A., Arya Sasmita, G., \& Dwi Rusjayanthi, N. (2016). Aplikasi Pengenalan Profil Negara di ASEAN Berbasis Augmented Reality. Merpati, 4(1), 162-169.

Astuti, I. A. D., Sumarni, R. A., \& Saraswati, D. L. (2017). Pengembangan Media Pembelajaran Fisika Mobile Learning berbasis Android. Jurnal Penelitian Dan Pengembangan Pendidikan Fisika, 3(1), 57-62.

Ayun, N., \& Rahmawati, I. (2018). Pengembangan Media Interaktif Si Pontar Berbasis Aplikasi Android Materi KPK Dan FPB Mata Pelajaran Matematika Kelas IV Sekolah Dasar. Jurnal Penelitian Pendidikan Guru Sekolah Dasar, 6(2), 254773.

Batubara, H. H. (2017). Pengembangan Media Pembelajaran Matematika Berbasis Android untuk Siswa SD/MI. Muallimuna: Jurnal Madrasah Ibtidaiyah, 4(1), 12-27.

Dewi, W. A. F. (2020). Dampak Covid-19 Terhadap Implementasi Pembelajaran Daring Di Sekolah Dasar. Jurnal Ilmu Pendidikan, 2(1), 55-61. https://doi.org/https://doi.org/10.31004/edukatif.v2i1.89.

Dini Savitri, Karim, A., \& Hasbullah. (2020). Pengembangan Media Pembelajaran Matematika Berbasis Android Di Kelas 4 Sekolah Dasar. Jurnal Lebesgue: Jurnal Ilmiah Pendidikan Matematika, Matematika Dan Statistika, 1(2), 63-75. https://doi.org/10.46306/lb.v1i2.17.

Erfan, M., Widodo, A., Umar, Radiusman, \& Ratu, T. (2020). Pengembangan Game Edukasi "Kata Fisikia" Berbasis Android untuk Anak Sekolah Dasar pada Materi Konsep Gaya. Lectura: Jurnal Pendidikan, 21(1), 31-46.

Firdaus, T. (2018). Pemanfaatan Media Berbasis Teknologi dalam Pembelajaran.

Hadi, S. (2017). Efektivitas Penggunaan Video Sebagai Media. Transformasi Pendidikan Abad 21, $96-102$.

Hamid, A. (2017). Guru Profesional. Jurnal Ilmiah Keislaman Dan Kemasyarakatan, 17(2), 274-285.

Hermawan, A. H. (2009). Pengembangan Kurikulum dan Pembelajaran. Universiitas Terbuka.

Kartini, K. S., \& Putra, I. N. T. A. (2020). Respon Siswa Terhadap Pengembangan Media Pembelajaran Interaktif Berbasis Android. Jurnal Pendidikan Kimia Indonesia, 4(1), 12. https://doi.org/10.23887/jpk.v4i1.24981.

Kharisma, G. I., \& Arvianto, F. (2019). Pengembangan aplikasi android berbentuk education games berbasis budaya lokal untuk keterampilan membaca permulaan bagi siswa kelas 1 SD/MI. Premiere Educandum: Jurnal Pendidikan Dasar Dan Pembelajaran, 9(2), 203. https://doi.org/10.25273/pe.v9i2.5234.

Lubis, M., Syafrilianto, \& Azizan, N. (2019). Penggunaan Media Pembelajaran Berbasis Android bagi Siswa SD/MI di Era Revolusi Industri 4.0. 11(1), 1-14. https://doi.org/doi.org/10.31227/osf.io/5xq6k.

Malyana, A. (2020). Pelaksanaan Pembelajaran Daring dan Luring dengan Metode Bimbingan Berkelanjutan pada Guru Sekolah Dasar di Teluk Betung Utara Bandar Lampung. Pedagogia: Jurnal Ilmiah Pendidikan Dasar Indonesia, 2(1), 67-76.

Mirnawati. (2020). Penggunaan Media Gambar dalam Pembelajaran untuk Meningkatkan Minat Baca Siswa. Jurnal Didaktika, 9(1), 98-112.

Muamanah, H., \& . S. (2020). Pelaksanaan Teori Belajar Bermakna David Ausubel Dalam Pembelajaran 
Pendidikan Agama Islam. Belajea; Jurnal Pendidikan Islam, 5(1), 161. https://doi.org/10.29240/belajea.v5i1.1329.

Muyaroah, S., \& Fajartia, M. (2017). Pengembangan Media Pembelajaran Berbasis Android dengan menggunakan Aplikasi Adobe Flash CS 6 pada Mata Pelajaran Biologi. Innovative Journal of $\begin{array}{lllll}\text { Curriculum } \quad \text { and } & \text { Educational }\end{array}$ https://doi.org/https://doi.org/10.15294/ijcet.v6i2.19336.

Nida, \& Dkk. (2020). Pengembangan Media Kartu Bergambar Berorientasi Pendidikan Karakter Pada Mata Pelajaran Bahasa Bali. Jurnal EDUTECH Universitas Pendidikan Ganesha., 8(1), 16-31.

Nurseto, T. (2012). Membuat Media Pembelajaran yang Menarik. Jurnal Ekonomi Dan Pendidikan, 8(1), 19-35. https://doi.org/10.21831/jep.v8i1.706.

Prasetyo, S. (2017). Pengembangan Media Pembelajaran Ipa Berbasis Android Untuk Siswa SD/MI. JMIE (Journal of Madrasah Ibtidaiyah Education), 1(1), 122-141. https://doi.org/10.32934/jmie.v1i1.29.

Ramdani, Z., Amrullah, S., \& Tae, L. F. (2019). Pentingnya Kolaborasi dalam Menciptakan Sistem Pendidikan yang Berkualitas. Mediapsi, 5(1), 40-48. https://doi.org/10.21776/ub.mps.2019.005.01.4.

Sriwitari, N. N., \& Widnyana, I. G. N. (2014). Desain Komunikasi Visual. Graha Ilmu.

Suartama, I. K. (2016). Materi 4 Evaluasi dan Kriteria Kualitas Multimedia Pembeajaran Oleh: I Kadek Suartama Jurusan Teknologi Pendidikan Universitas Pendidikan Ganesha Tahun 2016. September.

Sudarma, I. K., Teguh, I. M., \& Prabawa, D. G. A. P. (2015). Desain Pesan Kajian Analitis Desain Visual Teks dan Image. Graha Ilmu.

Sudrajat, B. (2018). Aplikasi Multimedia Interaktif Pengenalan Negara ASEAN Untuk Siswa Kelas VI SD. Jurnal Interkom, 13(1), 11-18.

Sulistyawati, T. E. (2020). Perspektif Aksiologi Terhadap Penurunan Minat Belajar Anak di Masa Pandemi. Aksiologi : Jurnal Pendidikan Dan Ilmu Sosial, 1(1), 33-43. https://doi.org/10.47134/aksiologi.v1i1.16.

Supriyono. (2018). Pentingnya Media Pembelajaran Untuk Meningkatkan Minat Belajar Siswa SD. Edustream: Jurnal Pendidikan Dasar, 2(1), 43-48. https://journal.unesa.ac.id/index.php/jpd/article/view/6262.

Susilo, A. K. (2017). Perancangan Aplikasi Mari Mengenal Negara Asean ( Mangga ) Untuk Siswa Sekolah Dasar Perancangan Aplikasi Mari Mengenal Negara. Informatika, Program Studi Ilmu, Fakultas Dan, Komunikasi Surakarta.

Syawaludin, A., Makkasau, A., \& Jamal, I. F. (2019). Pengembangan Media Pembelajaran Aplikasi Lectora Inspire pada Mata Pelajaran IPS Kelas V di SDN 197 Sapolohe Kecamatan Bontobahari Kabupaten Bulukumba. Jurnal Ilmiah Ilmu Kependidikan, 3(3), $294-306$. https://doi.org/https://doi.org/10.26858/jkp.v3i3.10236.

Tahel, F., \& Ginting, E. (2019). Perancangan Aplikasi Media Pembelajaran Pengenalan Pahlawan Nasional untuk Meningkatkan Rasa Nasionalis Berbasis Android. Teknomatika, 9(02), 113-120.

Tambunan, R. U., Suryadi, S., \& Purnama, I. (2017). Perancangan Aplikasi Data Buku Perpustakaan Pada Smk Swasta Al - Azis Berbasis Anroid. Jurnal Ilmiah AMIK, 5(2), 46-52.

Tegeh, I. M., Jampel, I. N., \& Pudjawan, K. (2014). Model Penelitian Pengembangan. Universitas Pendidikan Ganesha.

Tegeh, I. M., \& Kirna, I. M. (2010). Metodelogi Penelitian Pengembangan Pendidikan. Universitas Pendidikan Ganesah.

Wahyuningtyas, R., \& Sulasmono, B. S. (2020). Pentingnya Media dalam Pembelajaran Guna Meningkatkan Hasil Belajar di Sekolah Dasar. Jurnal Ilmu Pendidikan, 2(1), 23-27.

Wardani, A., \& Ayriza, Y. (2020). Analisis Kendala Orang Tua dalam Mendampingi Anak Belajar di Rumah Pada Masa Pandemi Covid-19. Jurnal Obsesi: Jurnal Pendidikan Anak Usia Dini, 5(1), 772. https://doi.org/10.31004/obsesi.v5i1.705.

Widyastuti, C. (2017). anggapan Siswa Kelas VII Terhadap Penggunaan Media Pembelajaran Dalam Pembelajaran Pendidikan Jasmani Olahraga Dan Kesehatan Di SMP Negeri 2 Pleret. Ekonomi, 5(5).

Wisada, P. D., Sudarma, I. K., \& Yuda S, A. I. W. I. (2019). Pengembangan Media Video Pembelajaran Berorientasi Pendidikan Karakter. Journal of Education Technology, 3(3), 140. https://doi.org/10.23887/jet.v3i3.21735.

Wulandari, I. G. A. A., \& Agustika, G. N. S. (2018). Pengaruh Gaya Kognitif Terhadap Hasil Belajar Matematika Pada Mahasiswa Semester IV Jurusan PGSD UPP Denpasar Universitas Pendidikan Ganesha Tahun Ajaran 2016/2017. Jurnal Ilmiah Sekolah Dasar, 2(1), 94. https://doi.org/10.23887/jisd.v2i1.15515. 